International Journal of Social Science And Human Research

ISSN(print): 2644-0679, ISSN(online): 2644-0695

Volume 05 Issue 01 January 2022

DOI: 10.47191/ijsshr/v5-i1-47, Impact factor-5.586

Page No: $337-346$

\title{
Legal Analysis Regarding Ex-Convicts as Election Contestants Based on the Indonesian Constitutional Court Decision
}

\author{
Arystha Nirwanto ${ }^{1}$, Ratna Herawati ${ }^{2}$ \\ ${ }^{1}$ Master of Law, Faculty of Law, Universitas Diponegoro \\ ${ }^{2}$ Faculty of Law, Universitas Diponegoro
}

\begin{abstract}
Ex-convicts must wait for a five-year gap after passing their prison term and announce their background if they want to run for governor, regent, or mayor, according to the Constitutional Court's decision Number 56/PUU-XVII/2019. The election of regional heads is an activity in the context of implementing a government system in the form of democracy. In the implementation of regional head elections, to get quality regional leaders, it takes qualified candidates promoted by political parties as well as those who run independently. Among the requirements for a regional head candidate, both at the provincial and district/city levels, a candidate must not be in a status of an ex-convict. The research method in this research was normative juridical. This research shows that based on the 1945 Constitution of the Republic of Indonesia, ex-convicts are also citizens who have the same political rights as other citizens. The existence of a provision that is a requirement to run as a candidate for the regional head in the election clearly limits or even negates a person's right to participate in exercising their rights. The decision of Constitutional Court No.42/PUU$\mathrm{XIII} / 2015$ states that ex-convicts can participate in regional head elections with certain conditions.
\end{abstract}

KEYWORDS: Convicts, Regional Head, Constitutional Court.

\section{A. PRELIMINARY}

Indonesia is a democratic and constitutional country. In a democratic country, general elections, including regional head elections, are means to actualize people's sovereignty to play an active role in the administration of the state. General elections in Indonesia are means to form a democratic government through an honest and fair mechanism (Zazili, 2012). It is implementing people's sovereignty which is held directly, publicly, freely, confidentially, honestly, and fairly in the Republic of Indonesia based on Pancasila and the 1945 Constitution of the Republic of Indonesia (Law of the Republic of Indonesia Number 15 of 2011).

Every human right must be protected, fulfilled, and enforced by the state. But, in its development, not all rights must be absolutely fulfilled, some rights can be limited in their fulfillment and some rights cannot be limited in their fulfillment even in an emergency. The rights that may be limited in their fulfillment in an emergency are the so-called derogable rights, which consist of the right to express opinions, the right to move, the right to assemble, and the right to speak.

However, some rights cannot be limited under all circumstances, those rights are called the non-derogable rights (rights that are absolute in nature which cannot be reduced by the fulfillment of the state parties, even in an emergency) which in principle include the right to life, freedom from acts of torture, freedom from acts that are inhuman and degrading, freedom from slavery and servitude, freedom from retroactive laws, and freedom of thought, conscience and religion (Matompo, 2014).

Law in Indonesia plays an important role in society and has multiple functions for the good of society to achieve justice, legal certainty, order, benefit, and other legal purposes. However, the opposite situation can occur even often, where state authorities use the law as a tool to suppress society so that people can be driven to where the state wants them (Nazarudin, 2017).

In realizing a just and prosperous society, it is necessary to have the leadership of regional heads who develop regions throughout the archipelago. General elections are recognized by countries that adhere to the principle of people sovereignty and are held at all types of political levels, whether democratic, authoritarian, or totalitarian systems. By some democracies, elections are considered a symbol and also a benchmark of the democratic system. (Budiardjo, 2009) Elections are a logical consequence of the adoption of democratic principles in the life of the nation and state, where the basic principle of democratic life is that every citizen has the right to actively participate in the political process.

To actualize the ideals of the Indonesian nation, the existence of regional leaders in all regions in the Republic of Indonesia must be led by a clean and authoritative Regional Head who is wise and responsible in leading the region that his power and authority in his position, both as Regional Head as well as their representatives who can provide public services for the community and can carry out their role as the leader of the Regional Head. 


\section{Legal Analysis Regarding Ex-Convicts as Election Contestants Based on the Indonesian Constitutional Court Decision}

Regional Heads have the responsibility to lead their regions, uphold a sense of unity and integrity for all Indonesian people, and the unity of the nation based on Pancasila and the 1945 Constitution. The national objective as stated in the Preamble to the 1945 Constitution is "Then from that to form an Indonesian State Government that protects the entire nation Indonesia and all of Indonesia's bloodshed, and in order to promote public welfare, educate the nation's life, and participate in carrying out world order based on independence, eternal peace and social justice, the independence of the Indonesian nationality were drawn up in a Constitution of the State of Indonesia, which was formed in an arrangement of the Republic of Indonesia with people's sovereignty based on: Belief in the One and Only God, just and civilized humanity, Indonesian unity, and democracy led by wisdom in deliberation/representation and by realizing social justice for all the people of Indonesia."

The requirements for the nomination of Legislative Members (DPD) and Regional Heads, of course, are not always acceptable and even contradict the interests of the wider community. As is the case with the requirement "Never as a convict for committing a criminal offense punishable by a minimum prison sentence of 5 (five) years or more based on a court decision that has permanent legal force or for former convicts who have openly and honestly stated to the public that the person concerned is a former convict. (Law Number 10 of 2016)

Human rights are owned by every human being as a gift from God Almighty since humans are born. By having human rights, they can demand that their basic rights be fulfilled, the state also guarantees these human rights as stated in Article 24 of the 1945 Constitution, therefore there is no reason for the human rights to be revoked. The inclusion of human rights provisions in the constitution as a form of guarantee for the rights of citizens to protect human rights (Krisnapati, 2018). So, human rights are not rights that are owned because they are given by the community or based on positive law, but because of their position as human beings. However, every country has an obligation to guarantee and respect human rights, protect and enforce them in their respective countries. (Kusniati, 2011)

Regarding a similar norm in the Election Law, the Constitutional Court Decision Number 4/PUU-VII/2009 stipulates that the legal norm is contrary to the 1945 Constitution if cumulative conditions are not met: (a) it does not apply to elected officials, as long as no additional punishment is imposed in the form of revocation of voting rights by a court decision that has permanent legal force; (b) is valid for a limited period of 5 (five) years after the former convict has finished serving his prison sentence based on a court decision that has permanent legal force; (c) honesty or openness about his background as a former convict; and (d) not as a repeat offender.

This research is normative juridical research, with a statute approach, and a case approach. (Marzuki, 2005) The statutory approach is carried out by examining the statutory provisions relating to the General Election and Regional Head Election. The case approach is carried out by examining the decisions of the Constitutional Court regarding the General Election and Regional Head Election. The legal materials in this study are primary legal materials and secondary legal materials. Primary legal materials are obtained from statutory regulations, and decisions of the Constitutional Court, while secondary legal materials are obtained from law books, and legal journals related to the General Election and Regional Head Election. The collected legal materials are then analyzed using legal interpretation techniques.

Based on the background that the author raised above, the discussion that will be discussed regarding ex-convicts advancing as election participants based on the decision of the Indonesian Constitutional Court which also found new things from research that was studied was gradually deepening in the formulation of the study as follows: (1) How is the form of provisions for former convicts declared constitutional by the Constitutional Court; (2) What are the mechanisms for selecting regional heads and the rules that govern them; and (3) How is the development of the Constitutional Court's Decision Regarding Ex-Convicts in the Nomination of Regional Heads.

This study used references to previous research conducted by several researchers who discussed ex-convicts and advanced candidates for Pilkada based on the decision of the Indonesian Constitutional Court. The results of previous studies will then be used as supporting material in this study. Research from Donal Fariz regarding the Restrictions on Rights for Former Corruption Convicts to Become Regional Head Candidates, related to the provisions for implementing diversion according to Decision Number 4/PUU-VII/2009, Decision Number 42/PUU-XIII/2015, and Decision Number 56/PUU-XVII/2019. (Fariz, 2020)

In this research, Marcus Mietzner discussed Reinventing Asian Populism Jokowi's Rise, Democracy, and Political Contestation in Indonesia. This study examined the declining role of political parties, and globalization creates socio-economic uncertainty that worries restless voters, anti-establishment figures or movements find it easy to attract attention and support. (Mietzner, 2021)

In this research, Stephen Sherlock discussed the study made by committee and consensus: parties and policy in the Indonesian parliament. This study examined political parties in the parliamentary arena in Indonesia which was still in its early stages. This has given rise to various assumptions about the way the party acts in the House of Representatives (DPR) which are based on little evidence and heavily influenced by the hostility towards the DPR in general in the media and the NGO community. The central party leader enforces strict discipline against its members in parliament, coordination between parties and caucuses, or factions, is weak, inconsistent. (Sherlock, 2021)

In this research, Muzayanah examined the juridical study of the political rights of ex-corruption convicts to run for regional head elections. This study conducted an assessment of the background of the implementation of How Juridical Studies on the Political Rights of Former Corruption Convicts to Run for Regional Head Elections and raised problems about whether ex-convicts of corruption cases still have political rights to be used as human rights in running for regional head elections. (Muzayanah, 2020)

Based on this research, Muhammad Lutfi Hardiyanto, Salahudin Serba Bagus, Ahmad Munir researched the Political Rights of Former Convicts to Run for Regional Head Candidates (Analysis of the Constitutional Court Decision No. 42/PUU-XIII/2015). This study 


\section{Legal Analysis Regarding Ex-Convicts as Election Contestants Based on the Indonesian Constitutional Court Decision}

conducted a background study as follows: what is the ratio decidendi of Constitutional Court Judges in the Constitutional Court Decision No. 42/PUU-XIII/2015 and what are the legal consequences of the decision of the Constitutional Court no. 42/PUU-XIII/2015 on the implementation of regional elections. (Hardiyanto, Bagus, Munir, 2017)

The initial part of this paper describes the concept of ex-convicts being able to run as participants in the regional elections based on the Indonesian Constitutional Court decision after passing a five-year gap after their imprisonment period and announcing their background if they want to run for the regional head. The Constitutional Court decision is widely associated with various existing laws, especially the 1945 Constitution which is the basis of the Indonesian state.

\section{B. RESEARCH METHOD}

Normative Juridical Research is a legal research method that is carried out by examining library materials or mere secondary materials. (Amirudin and Zainal, 2004; Achmad, 2009) This research is normative juridical research on issues related to the synchronization of regional head elections with the Constitutional Court decisions. The data in the article is part of the results of the research, entitled Legal Analysis Regarding Ex-Convicts as Election Contestants Based on the Indonesian Constitutional Court Decision. The data analysis method was carried out by collecting data through the study of library materials or secondary data which includes primary legal materials, secondary legal materials, and tertiary legal materials, both in the form of documents and applicable laws and regulations relating to normative juridical analysis.

Because this research was only aimed at written regulations, this research is very closely related to the library because it will require secondary data in the library. The specification of the research was carried out in an analytical descriptive manner, how to describe the state of the object under study, the applicable law, and its current implementation based on facts and data at this time. This study used several data sources, both primary data, and secondary data as well as tertiary data. With details of secondary legal material, namely the decision of the Constitutional Court Number 56/PUU-XVII/2019 regarding ex-convicts having to wait for a 5year gap if they want to become run for Regional Head Election. The secondary legal materials for this research come from books, scientific journals, various articles, and other sources related to this research.

\section{RESULTS AND DISCUSSION}

\section{Provisions for Ex-Convicts Declared Constitutional by Constitutional Court}

Based on the 1945 Constitution which adheres to the understanding of the sovereignty of the Indonesian people which includes both aspects of political and economic democracy. Based on these two democratic doctrines, the social system in Indonesia can be developed according to balanced democratic principles, thereby fostering a strong social democratic culture. In the notion of social democracy, the state functions as a tool of welfare (welfare state), although the waves of liberalism and capitalism continue to develop and affect almost all human life, there is still adjusting to the constructive elements of socialism in the form of market socialism. (Asshiddiqie, 2012)

Pancasila as the basis of the Republic of Indonesia states in the fifth principle of social justice for all Indonesian people. This precept means that there should be no discriminatory treatment for all people of the nation in all areas of life unless otherwise required by law or a judge's decision. The implementation of this is embodied in Article 27 paragraph (1) of the 1945 Constitution which states that there are no exceptions to the right to equal status in law and government. Article 28D paragraph (3) of the 1945 Constitution states the right to have equal opportunities in government. Based on this, it is stated that discrimination against citizens is an act that is prohibited by the constitution.

The Constitutional Court Decision Number 14-17/PUU-V/2007 dated December 11, 2007, has rejected the application for review of Article 58 letter f of Law Number 32 of 2004 concerning Regional Government, Article 6 letter t of Law Number 23 of 2003 regarding the General Election of the President and Vice President, Article 16 paragraph (1) letter d of the Constitutional Court Law, Article 7 paragraph (2) letter d of Law Number 5 of 2004 concerning Amendments to Law Number 14 of 1985 concerning the Supreme Court, and Article 13 letter g of Law Number 16 of 2006 concerning the Supreme Audit Agency, all of which test the condition that "never have been sentenced to imprisonment based on a court decision that has permanent legal force for committing a crime punishable by imprisonment of 5 years or more".

In the consideration of the decision, it was stated that the articles of various laws being tested were declared as conditionally constitutional, i.e. exemptions for crimes of minor negligence (culpa levis) and crimes due to differences in political views. The things that are considered in this decision concerning the specifics of the character of certain public positions cause not all public positions to be determined with requirements using a general formulation of norms so that it is necessary to differentiate the requirements, among others: 1. Elected public positions (elected officials) and appointed public positions (appointed officials) 2 . Public positions in the executive field are more of a service nature and public positions in the legislative sector which are channeling the aspirations of the people, and public positions which because of their duties require a very high level of trust, such as judges and other law enforcement officers, and officials who manage state finances.

The sociological and historical considerations of the Constitutional Court in deciding this case were the amnesty policy against members of PRRI/Permesta and GAM who at that time had also committed crimes that were quite serious and threatened 


\section{Legal Analysis Regarding Ex-Convicts as Election Contestants Based on the Indonesian Constitutional Court Decision}

with punishment according to positive Indonesian law. The parties involved in the G.30.S/PKI rebellion whose requirements were not involved directly or indirectly to become candidates for members of the DPR, DPD, and DPRD have been declared unconstitutional by the Court through decision Number 11-17/PUU-I/2003 February 24, 2004.

The legal norm in the a quo decision is unconstitutional if the following conditions are not met: (MK 2007 Decision) 1) It does not apply to elected officials as long as there is no additional penalty in the form of revocation of voting rights by a court decision which already has permanent legal force; 2) Valid for a limited period of 5 (five) years after the former convict has finished serving his prison sentence based on a court decision that has permanent legal force; 3) Honesty or openness regarding his background as a former convict; 4) Not as a repeat offender; 5) Never been sentenced to imprisonment based on a court decision that has permanent legal force for committing a crime punishable by imprisonment of 5 years or more," if enforced without certain conditions, it can negate the principle of equality in law and government and violate the rights of a person or citizen, the state for fair treatment, guarantees, protection, and legal certainty, as well as an equal treatment before the law, and the right to get equal opportunities in government which are essentially legal morality and constitutional morality.

Reading the a quo decision must be an integral part that must be fulfilled as a whole. If one of the provisions is not fulfilled, then an ex-convict is not entitled to become a candidate in regional head elections and general elections. Researchers using the concept of progressive law to produce new concepts on an issue need free-thinking and dare to get out of the status quo. Progressive comes from the word progress which means advancement and/or improvement. Law should be able to keep up with the times, be able to respond to changing times, with all the basics in it, and be able to serve the community by relying on aspects of morality and human resources of law enforcers themselves.

Election law must be able and quickly respond to changes in society that occur. Forcing electoral laws to continue to apply makes law enforcement ineffective. Or imposing election law on the community or tending to enforce the law, giving birth to rejection and even conflict in the community. The idea of progressive law starts from the basic philosophical assumption that law is for humans, not the other way around. Thus, the existence of law is to serve and protect humans, not the other way around. Law is considered an institution that aims to deliver humans to a just and prosperous life and bring pleasure to human life. Progressive law adheres to a pro-justice and pro-people legal ideology. (Rahardjo, 2009)

Satjipto Rahardjo describes that the law is always in the process by saying that: the law is an institution that continuously builds and changes itself towards a better level of perfection. The quality of perfection here can be verified into factors of justice, welfare, concern for society, and others. This is the essence of "law is always in the process of becoming" (law as process, law in the making). Law does not exist for the law itself but humans. (Rahardjo, 2005) Progressive law discoveries explicitly link legal factors, humanitarian and morality, so that legal discoveries made by judges within the framework of carrying out their judicial duties will ultimately make their decision. Therefore, the character of progressive law is: (Rivai, 2010)

1. The discovery of law based on the judge's appreciation guided by his views and thoughts independently, based on the view that the law exists to serve humans.

2. The discovery of law based on legal values, truth, and justice as well as ethics and morality.

3. The discovery of laws that can create new values in people's lives, or carry out engineering in society following the times and technology as well as the conditions of society.

Through the decision Number 42/PUU-XIII/2015, one of which examines Article 7 paragraph (2) letter g of Law Number 8 of 2015 related to "never as a convict based on a court decision that has obtained permanent legal force or for former convicts has publicly and honestly stated to the public that the person concerned was a former convict", became a breakthrough in managing a substantial local democratic system and a progressive step in the implementation of people's sovereignty. According to J. Jacques Rousseau, the concept of sovereignty is populist and is based on the general will (volunte generale) of the people which is manifested through legislation. Therefore, according to him, the concept of sovereignty has the following characteristics: (1) unite, monistic; (2) round and undivided (indivisibilite); (3) non-transferable (inalienablelite); and (4) cannot be changed (imprescriptibilite). (Asshiddiqie, 2011)

In the court's consideration, when Article 7 letter $g$ of the Regional Election Law determines that a candidate for regional head must meet the requirements of having never been sentenced to a criminal offense for committing a criminal offense which is punishable by imprisonment for a maximum of five years or more, then it means that someone who has been sentenced to a criminal offense has committed a crime, who are punishable by a sentence of 5 years or more, their right to be elected in the Regional ELection is revoked. This is in line with the provisions of Article 35 paragraph (1) number 3 of the Criminal Code that a convict's right can be revoked regarding "the right to vote and be elected in elections held based on general rules". The difference is that if the right to be elected as a regional head is revoked based on Article 7 letter $g$ of the Regional Election Law, it is carried out by legislators, while the right to be elected as a convict is revoked based on Article 35 paragraph (1) of the Criminal Code is carried out by a judge's decision. (MK's decision, 2015) If the law limits the right of an ex-convict not to be able to nominate himself as a regional head, it means that the law has given additional punishment to the person concerned, while the constitution prohibits discrimination against all members of the society. 


\section{Legal Analysis Regarding Ex-Convicts as Election Contestants Based on the Indonesian Constitutional Court Decision}

\section{Mechanism of Regional Head Election and Provisions That Regulate It}

The General Election is a democratic party in the context of actualizing people's sovereignty, which provides an opportunity for all citizens to democratically elect their representatives and leaders for the sake of increasing welfare. As the basis for the implementation of the General Election, Article 22E paragraph (1) of the 1945 Constitution of the Republic of Indonesia mandates that the General Election be held with higher quality by involving the widest possible participation of the people on the principles of democracy, direct, general, free, confidential, honest and fair through a law. Elections in a democracy are held to fill political positions, both legislative and executive, which are the most open positions. (Handayani, 2014)

The dispute over the results of the general election of regional heads which has become one of the powers of the Constitutional Court to examine, hear and decide since October 2008, is based on Article 236C of Law Number 12 of 2008 concerning the Second Amendment to Law Number 32 of 2004 concerning Regional Government. The transfer of authority from the Supreme Court as the institution that originally handled the dispute to the Constitutional Court, which is said to be the guardian of the constitution, is actually not only a transition of the institution that handles it but also a transition accompanied by changes in the character of dispute resolution within the framework of maintaining and overseeing the democratic process in the constitutional framework, so that the possibility is wide open, in addition to examining and adjudicating disputes over the results of the vote that affect the election of candidate pairs for regional heads in a trial process, as well as to concretely examine the norms in the laws and regulations governing the regional head election process.

The implementation of regional head elections is a correction to the implementation of regional head elections through people's representatives in DPRD based on Law Number 22 of 1999 concerning Regional Government. The correction to the regional head election system was carried out by implementing the legal umbrella for direct regional head elections, namely Law Number 32 of 2004. In further developments, Law Number 32 of 2004 was later amended by Law Number 12 of 2008 . The enactment of Law Number 12 of 2008 is actually inseparable from the debate that has developed in the community regarding the existence of regional head elections. Article 18 paragraph (4) of the 1945 Constitution as the constitutional basis for the implementation of regional head elections was born at the same time as Article 18A and Article 18B, namely in the second amendment to the 1945 Constitution and was included in Chapter on Regional Government. Furthermore, Article 22E was born through the third amendment to the 1945 Constitution but did not include Article 18 paragraph (4) but only the provisions of Article 18 paragraph (3) which regulates the DPRD. (Nopyandri, 2013)

Based on PKPU Number 20 of 2018 concerning the Nomination of Legislative Members, in its article it states the conditions that must be followed in the nomination where one of them is "never been sentenced to imprisonment for 5 years or more", then in paragraph (4), it is stated about the conditions that must be met. as stated in this rule, to register as a legislative candidate, exceptions are made for:

a. For former convicts who have completed their criminal period and are willing to openly and honestly announce to the public, they are not repeat offenders, and include their curriculum vitae.

b. For convicts who are caused by minor negligence and some do not carry out their sentences in prison and are open and honest in conveying to the public the election of members of the legislature, both DPR, Provincial DPRD, Regency/Municipal DPRD. (Anwar and Saraswati, 2018)

The international standards for democratic election administration developed by The Organization of Democratic Institution and Human Rights (ODIHR)-(OSCE) and The Institute for Democracy and Electoral Assistance (IDEA) state that restrictions or restrictions on the right to vote are allowed with a record of restrictions and restraints it is justified by circumstances or based on recognized norms. (Muhammad Anwar Tanjung and Retno Saraswati, 2018) In the process, the election mechanism underwent several changes from indirect elections to direct elections. This dynamic is motivated by various reasons such as the 'affair' of the people's representatives (DPRD) with the candidates for Regent/Mayor/Governor which has an impact on political corruption and opaque accountability because the conspiracy of the political elite negates transparency but instead brightens up money politics. This is possible because it is the DPRD that elects regional heads. This reason is the peak of dissatisfaction with the implementation of indirect elections. Thus there is a change from Law no. 22/1999 was replaced by Law no. 32/2004 which regulates local elections directly. (Suyatno, 2016)

Direct regional head elections have a very close correlation with the implementation of popular sovereignty. With direct regional head elections, the people can determine their own leaders in their regions, so that a close relationship is established between regional heads and the people which can encourage the realization of democratic and participatory regional governance. The direct regional head election system provides several advantages, namely: first, the elected regional head will have a strong mandate and legitimacy because it is supported by the people who vote directly. Legitimacy is something that is needed by a government that is experiencing a political and economic crisis. The crisis of legitimacy that undermines the leadership of regional heads will result in political and economic instability in the regions.

Second, the elected Regional Head does not need to be tied to the concessions of the party or political factions that have nominated him. This means that the elected Regional Head is above all interests and can bridge these various interests. If the elected 


\section{Legal Analysis Regarding Ex-Convicts as Election Contestants Based on the Indonesian Constitutional Court Decision}

regional head cannot overcome the interests of political parties, then the policies taken tend to compromise the interests of the parties and are often at odds with the interests of the people.

Third, the direct regional head election system is more accountable than other systems that have been used so far because the people do not have to entrust their votes to members of the legislature partially or fully. The people can make their choice based on the interests and assessment of the candidate. If the elected Regional Head does not meet the people's expectations, then in the next election, the candidate concerned will not be re-elected. This principle is the simplest principle of supervision and accountability and can be understood by the people and politicians.

Fourth, checks and balances between the legislative and executive institutions can be more balanced. With a direct regional head election system, the position of the regional head is very strong so that the DPRD as a regional legislative body cannot pressure the regional head over a policy or pressure the regional head to fulfill the wishes and demands of the DPRD. Thus, regional heads can work calmly to implement their work programs without having to be disturbed by the demands of the DPRD. Nevertheless, regional heads must still pay attention to the opinion of the DPRD regarding the implementation of DPRD functions as regulated in laws and regulations.

Fifth, the criteria for regional head candidates can be assessed directly by the people who will cast their votes. Because the people will determine their regional head, the people can determine the ideal criteria for a regional head candidate. With the criteria determined by the people themselves, the people will choose one candidate for the regional head. Thus the people's choice is determined by the people themselves.

However, it must also be noted that the direct regional head election system also has weaknesses, namely: the funds required are very large. Direct regional head elections require very large funds or budgets for operational, logistical, and security needs. The amount of costs that must be prepared in holding direct regional head elections is not only a burden that must be borne by regional head candidates but also must be borne by regional governments. The cost of direct regional head elections will be even more severe when regional head elections must be held in two rounds (two rounds).

Direct regional head elections in the era of political liberalization with the power of a dominant political party, it is very possible that those who can fight have strong economic and political capital. (Amirudin and Bisri, 2006) Entrepreneurs who are close to political parties or wealthy incumbents are the ones who have the greatest chance of being included in the candidacy market for regional head elections. Based on financial capability and the strength of this economic capital, those who can enter the regional leadership market are not competent figures who have good capabilities, but only those who are included in the group of rich people or have strong financial capabilities. Second, it opens the possibility of conflict between the elite and the masses. The direct election of regional heads opens the potential for conflict, both elite conflicts, and horizontal mass conflicts.

This conflict is more likely to occur in paternalistic and primordial societies, where leaders can mobilize supporters. Third, people's activities are disrupted. The direct election of regional heads will be busy with the activities of the candidates and their supporting political parties to conduct campaigns and disseminate political issues as well as carry out direct maneuvers among the people with the intention of influencing people's choices. Therefore, in the splendor of the implementation of direct regional head elections, it has caused a disturbance to the routine activities of the community, where the community will also be busy with activities related to the implementation of the regional head election.

The basic issue regarding regional head elections is generally related to the understanding and meaning of the word "democratic" which is then debated as direct elections which are called democratic and other opinions which state that indirect elections can also be democratic. The mechanism for electing regional heads is called democratic if it fulfills several parameters. Robert Dahl, Samuel Huntington (1993), and Bingham Powel (1978) as quoted by Saukani, HR, and colleagues said that the parameters for observing the realization of democracy include: general elections, rotation of power, open recruitment, and public accountability. (Saukani HR, Affan Gaffar, and Ryass Rasyid, 2002)

Besides this has become the belief of the constitutional judges, the practice and jurisprudence of the Constitutional Court are rich enough to demonstrate this. It can never be justified that in the process of the general election for regional heads, there were violations that clearly contradicted the constitutional norms which became the principles that must be maintained in the framework of guarding one form of democracy direct, general, free, secret, honest elections, and fair. Debates on objectum litis that shift responsibility for violations in the electoral process that are not handled properly and appropriately by organizers, supervisors, and law enforcement before the results of the voting results are announced by the KPU, may not be examined and decided by the Constitutional Court in the process of disputes over the results of the general election. concerning the acquisition of votes, has passed. It is a truth that is agreed upon by all parties, that the process will definitely affect the results. (Article 103 of Law Number 32 of 2004)

The decisions of the Constitutional Court move dynamically to strengthen constitutional principles in practice, guarding the realization of honest and fair regional head elections as a recruitment process for government leaders. The shift in approach to dispute resolution on the results of the regional head elections that occurred and was carried out by the Constitutional Court must have met with resistance from certain parties, who felt disadvantaged, including the organizers of the General Elections themselves, 


\section{Legal Analysis Regarding Ex-Convicts as Election Contestants Based on the Indonesian Constitutional Court Decision}

who had determined the results of certain regional head elections, which were influenced by one process that is not following the above constitutional principles.

3. The Development of the Constitutional Court's Decision Regarding Ex-Convicts in the Nomination of Regional Heads

The Law on the Election of Regional Heads includes several arrangements that differ from one another, particularly concerning the terms of candidacy. The development of the Constitutional Court's decision in question is a requirement for former convicts to have been sentenced to imprisonment based on a court decision that has obtained permanent legal force for committing a criminal act which is punishable by a maximum imprisonment of 5 (five) years or more.

The direct regional head election which implementation began in 2005 was using Law no. 32 of 2004 concerning Regional Government. In the records of the Association for Elections and Democracy (Perludem), the legal basis for holding the elections for the 2005-2008 period used the law which later underwent two changes: first, through Law No. 8 of 2005 concerning Stipulation of Government Regulations in Lieu of Law No. 3 of 2005 concerning Amendments to Law Number 32 of 2004 concerning Regional Government, becoming Law (UU No 8/2005); and, secondly, through Law Number 12 of 2008 concerning the Second Amendment to Law Number 32 of 2004 concerning Regional Government. (Hanafi, 2014)

Limitation of rights for former convicts who have completed their sentences for committing criminal acts, one of which is corruption. This article has been tested repeatedly at the Constitutional Court and has experienced the following dynamics of meaning:

a) Constitutional Court Decision Number 4/PUU-VII/2009

In its Decision Number 4/PUU-VII/2009, the Constitutional Court stated Article 12 letter g and Article 50 paragraph (1) letter $\mathrm{f}$ of Law no. 10 of 2008 and Article 58 letter $\mathrm{f}$ of Law no. 12 of 2008 as a conditionally unconstitutional legal norm if the following conditions are not met: (MK Decision, 2009)

1. It does not apply to elected officials as long as they are not subject to additional punishment in the form of revocation of voting rights by a court decision that has permanent legal force;

2. Valid for a limited period of 5 (five) years after the former convict has finished serving his prison sentence based on a court decision that has permanent legal force;

3. Honesty or openness regarding his background as a former convict;

4. Not as a repeat offender;

Based on the description above, it can be understood that the Constitutional Court actually gave an interpretation of Article 58 letter $\mathrm{f}$ of Law Number 32 of 2004 concerning Regional Government.

With that interpretation, even though in its decision it was stated that it rejected the application, the Constitutional Court gave meaning to the constitutionality of the application of these conditions. The Court assessed that the four conditions apply cumulatively. For ex-convicts, one of whom is convicted of a corruption case whose entire action in the Corruption Crime Act is threatened with a sentence of more than 5 years, then this provision is enforced. The gap period is enforced for 5 years from the time the person concerned has finished serving the criminal period is intended as a corrective phase for the actions that have been committed. Then it is also required to publicly announce to the public the actions he has committed. As a follow-up to the nomination of regional heads, the General Election Commission accommodates the KPU Regulation (PKPU).

b) Constitutional Court Decision Number 42/PUU-XIII/2015

The Constitutional Court again tried and examined the case regarding the prohibition of candidacy for former convicts with the threat of a sentence of more than 5 years under a different law. The provision in question is Article 7 letter $\mathrm{f}$ of Law no. 8 of 2015 concerning Regional Head Elections. The Constitutional Court in its Decision Number 42/PUU-XIII/2015 was declared partially granted, which was conditionally declared contrary to the 1945 Constitution as long as it was not interpreted except for former convicts who openly and honestly stated to the public that the person concerned was a former convict. (MK Decision, 2015)

The decision was based on the reason that the existence of the conditions as contained in Article 7 letter $g$ of Law no. $8 / 2015$ is considered as a reduction in the right to honor and is equated with a criminal revocation of certain rights. Meanwhile, according to the Constitutional Court, the revocation of a person's right to vote can only be carried out by a judge's decision as an additional punishment for him. (MK's decision, 2015) To avoid conflicts with the Constitutional Court's decision and the criminal concept, the legal norms were changed and limited to a certain period of time after serving imprisonment.

This is based on the strength of the court's decision which refers to the power of administrative law with a reasonable and reasonable time limit following the principle of due process of law in criminal law enforcement since the convict has finished serving his sentence as was imposed in the previous Decision Number 4/PUU-VII/2009. This requirement becomes unnecessary if a convict has bravely admitted his status as an ex-convict. In a sense, if an ex-convict has finished serving his sentence and announces openly and honestly that he is an ex-convict, then the person concerned can run for governor, regent, and mayor. The Constitutional Court's decision then contradicts the previous conditions that apply cumulatively, turning into an alternative by simply announcing it to the public.

This is the problem with the Constitutional Court Decision Number 42/PUU-XIII/2015. There is no comprehensive explanation why the Constitutional Court changed its view compared to the previous decision. Even the Court's decision was not 


\section{Legal Analysis Regarding Ex-Convicts as Election Contestants Based on the Indonesian Constitutional Court Decision}

taken unanimously, but two Constitutional Judges expressed dissenting opinions, namely Judge Maria Farida Indrati and Judge I Dewa Gede Palguna. The two Constitutional Judges believe that the interpretation of the "condition of never being convicted" has been completed. The conditions stated in the Constitutional Court Decision Number 4/PUU-VII/2009 apply cumulatively and this has been implemented by the legislators by making changes to the law and placing it in the explanation of the article.

Even Constitutional Judge I Dewa Gede Palguna asserted that there were no fundamental constitutional reasons, which resulted in the need for the Court to change its stance as stated in previous decisions. The conditions stated by the Constitutional Court in Decision Number 42/PUUXIII/2015 have been adopted for the requirements to become candidates for members of the DPR, DPD, and DPRD. The norm of the requirements is contained in Article 182 letter h for the DPD and Article 240 paragraph (1) letter $g$ for the DPR and DPRD with the exact same formulation, namely: never been sentenced to imprisonment based on a court decision that has obtained permanent legal force for committing a criminal act committed threatened with imprisonment of 5 (five) years or more unless openly and honestly state to the public that the person concerned is a former convict.

c) Constitutional Court Decision Number 56/PUU-XVII/2019

In the provisions of Law Number 10 of 2016 concerning the Second Amendment to Law Number 1 of 2015 concerning Stipulation of Government Regulations in Lieu of Law (Perpu No. 1, 2014) Number 1 of 2014 concerning Election of Governors, Regents and Mayors Law No. 10 of 2016 Other provisions in article 7 paragraph 2 letter g stipulate: never as a convict based on a court decision that has permanent legal force or for former convicts have openly and honestly stated to the public that the person concerned is a former convict; This article was then again challenged to the Constitutional Court.

The lawsuit was filed by the Indonesian Corruption Watch (ICW) and the Association for Elections and Democracy (Perludem). In their petition, the Petitioners asked the Court again to interpret the a quo article as stated in the Constitutional Court Decision Number 4/PUU-VII/2009. In fact, the Petitioners asked for the waiting period which was originally 5 (five) years to be increased to 10 (ten) years. In full, the petition reads "Prospective governor and deputy governor, candidate for regent and candidate for deputy regent, as well as candidate for mayor and candidate for deputy mayor as referred to in paragraph (1) must meet the following requirements: $g$. has never been a convict based on a court decision that has obtained permanent legal force for committing a crime punishable by imprisonment of 5 (five) years or more, except for the convict who commits a criminal act of negligence and a political crime in the sense of an act which is declared an offense criminal law in positive law only because the perpetrator has a different political view from the regime in power; not sentenced to additional punishment in the form of revocation of voting rights by a court decision that has permanent legal force; for former convicts, a period of 10 (ten) years has passed after the former convict has finished serving his prison sentence based on a court decision that has permanent legal force; be honest or open about his background as a former convict; and not as a repeat offender. (ICW, 2019)

The Constitutional Court's Decision Number 14-17/PUU-V/2007 in its decision rejected the examination of several articles regarding ex-convicts who wished to register in elections following the regulations related to elections. This decision is stated in articles of various rules which are stated as conditionally constitutional, namely those who are not allowed to commit crimes or minor negligence. KPU issued PKPU which regulates corruption convicts to register as members of the legislature. The existence of this problem, the Supreme Court examines the regulations from the KPU. Finally, the Supreme Court also issued Supreme Court Decision Number $46 \mathrm{P} / \mathrm{HUM} / 2018$ in which the results of the examination rejected the rules made by the KPU, the material was tested and the results of the decision returned to the Election Law. Have never experienced imprisonment for a decision made by a court and have permanent legal power, if making a criminal act can be threatened 5 years or more, and if this regulation is still enforced without proper conditions, it can negate the existence of a principle of equality in law and government as well as those who violate the rights of a person or citizen. (Hapsari, 2018)

The Constitutional Court in its decision Number 56/PUU-XVII/2019 granted in part the petition. In its decision, the Constitutional Court reactivated the four requirements for former convicts as decided in case Number 4/PUU-VII/2009 and did not grant an additional 10 (ten) year waiting period for former convicts who had finished serving their sentences. However, decision Number 56/PUU-XVII/2019 can be interpreted as a correction to the previous Constitutional Court decision (42/PUU-XIII/2015) which eliminated the cumulative requirement for nominations for regional heads with the status of former convicts.

In their consideration, the constitutional judges referred back to the Court's decision which eliminated the cumulative requirement as stated in the Constitutional Court's Decision Number 4/PUU-VII/2009 which made it an alternative condition so that the requirements became looser with consideration to return to the community as voters who have sovereignty. to make his choice. Empirical facts prove that among elected regional heads who have served a criminal period to become regional head candidates only by taking the alternative of announcing honestly and openly to the public that the person concerned is an ex-convict has repeated the crime. (MK's Decision, 2019)

\section{CONCLUSION}

The Constitutional Court's decision guarantees the constitutional rights of ex-convicts to participate as regional head candidates and legislative candidates in regional head elections and general elections. The decision gives legality to ex-convicts to occupy elected public positions (elected officials) as long as they are not subject to additional penalties in the form of revocation of voting rights 
by court decisions that have legal force. This decision of the Constitutional Court must be interpreted as a source of law that is final and binding by the election organizers which regulates not limits human rights.

Efforts by election administrators to build democracy must be seen as good faith to ensure that regional head elections take place democratically. This effort is carried out by issuing implementing technical regulations to implement the decisions of the Constitutional Court as required a quo. The material of the regulation must include strict sanctions for ex-convicts who do not meet the provisions in the regulation, both before and after being appointed as regional heads and candidates for members of the DPR, Provincial DPRD, and Regency/Municipal DPRD.

Bawaslu as an election supervisory agency must oversee the process of nominating regional heads and legislative candidates so that they comply with the provisions of the applicable laws and regulations. Political parties are the main determinants of the success of holding elections and democratic regional head elections. Political parties have an important role in producing candidates for members of DPR, Provincial DPRD, and Regency/Municipal DPRD who are professional and with integrity. Mistakes in placing candidates who will compete will bring a bad image to the supporting political parties. This can be done by conducting good cadre and tiered political education which must be an integral part of the existence of political parties.

\section{BIBLIOGRAPHY}

\section{Journals}

1) Achmad Ali. 2009. Menguak Teori Hukum (Legal Theory) \& Teori Peradilan (Judicialprudence): Termasuk Interpretasi Undang-undang (Legisprudence). Kencana.

2) Ahmad Zazili, "Pengakuan Negara Terhadap Hak-hak Politik (Rigth to Vote) Masyarakat Adat Dalam Pelaksanaan Pemilihan Umum”, Jurnal Konstitusi, Vol .9 No. 1, 2012.

3) Anwar Tanjung Muhammad dan Saraswati Retno, "Demokrasi dan Legalitas Mantan Narapidana dalam Pemilihan Kepala Daerah dan Pemilihan Umum”, Jurnal Hukum IUS QUIA IUSTUM, Volume 25, Nomor 2, Mei 2018.

4) Faris, Donald (2020) Pembatasan Hak bagi Mantan Terpidana Korupsi Menjadi Calon Kepala Daerah Restrictions of Former Convicted Corruption Becoming Regional Head Candidates, Jurnal Konstitusi, Volume 17, Nomor 2, Juni 2020.

5) Hanum Hapsari, 2018, "Dilema Pelarangan Mantan Narapidana Korupsi Mendaftarkan Diri Sebagai Calon Legislatif", Jurnal Nasional, Vol. 4 No. 2, Surakarta.

6) Hanafi, R. I. (2016). Pemilihan Langsung Kepala Daerah di Indonesia: Beberapa Catatan Kritis Untuk Partai Politik. Jurnal Penelitian Politik, 11(2),16.https://doi.org/10.14203/jpp.v11i2.197.

7) Hardiyanto Muhammad Lutfi, Bagus Shalahudin Serba, Munir Ahmad (2017) Hak Politik Mantan Narapidana Untuk Mencalonkan Diri Sebagai Calon Kepala Daerah (Analisis Terhadap Putusan MK. No. 42/PUU-XIII/2015), MIMBAR YUSTITIA Vol. 1 No.2 Desember 2017.

8) Johny Ibrahim, Teori \& Metode Penelitian Hukum Normatif, Bayu Media, Malang, 2011.

9) Krisnapati, Bayu, Kodrat Manusia Mendapatkan Access To Justice, Jurnal Hukum Justitia et Pax, Volume 34 Nomor 2 , Desember 2018.

10) Kusniati, Retno, Sejarah Perlindungan Hak Hak Asasi Manusia, Konsepsi Negara Hukum, Jurnal Ilmu Hukum: INOVATIF, Volume 4 Nomor 5, 2011.

11) Lathif, Nazaruddin (2017), “Teori Hukum Sebagai Sarana/Alat Untuk Memperbahatui atau Merekayasa Masyarakat”, Pakuan Law Review, Vol. 3 No. 1.

12) Muhak asasi manusiamad Anwar Tanjung dan Retno Saraswati, 2018, "Demokrasi dan Legalitas Mantan Narapidana dalam Pemilihan Kepala Daerah dan Pemilihan Umum”, Jurnal Hukum, Vol 25 No. 2, Semarang.

13) Muzayanah (2020) Kajian Yuridis Terhadap Hak Politik Mantan Narapidana Korupsi Untuk Mencalonkan Diri Pada Pemilihan Kepala Daerah, Jurnal Komunikasi Hukum (JKH) Universitas Pendidikan Ganesha Vol. 6 No. 2 , Agustus 2020.

14) Mietzner, Marcus (2021) Reinventing Asian Populism Jokowi’s Rise, Democracy, and Political Contestation in Indonesia, 182.255.0.242 on Mon, 15 Mar 2021 00:05:34 UTC All use subject to https://about.jstor.org.terms.

15) Nopyandri, (2013) Pemilihan Kepala Daerah Yang Demokratis Dalam Perspektif Uud 1945, Jurnal Ilmu Hukum, Volume 2 No. 2.

16) Osgar, S. Matompo, (2014) "Pembatasan Terhadap Hak Asasi Manusia Dalam Perspektif Keadaan Darurat", Jurnal Media Hukum, Vol. 21 No. 1.

17) Rahardjo Satjipto, "Hukum Progresif: Hukum Yang Membebaskan”, artikel dalam Jurnal Hukum Progresif, Vol 1/No.1, April 2005, Program Doktor Ilmu Hukum Universitas Diponegoro, 2005.

18) Sherlock, Stephen (2021) Made by committee and consensus: parties and policy in the Indonesian parliament, 182.255.0.242 on Mon, 15 Mar 2021 00:09:48 UTC All use subject to https://about.jstor.org.terms.

19) Suyatno (2016) Pemilihan Kepala Daerah (Pilkada) dan Tantangan Demokrasi Lokal di Indonesia, Politik Indonesia: Indonesian Political Science Review 1 (2) (2016) 212-230. 


\section{Legal Analysis Regarding Ex-Convicts as Election Contestants Based on the Indonesian Constitutional Court Decision}

20) Yeni Handayani (2014) Hak Mantan Narapidana Sebagai Pejabat Publik Dalam Perspektif Hak Asasi Manusia, Jurnal Rechtsvinding Online, Media Pembinaan Hukum Nasional.

\section{Books}

1) Amirudin dan Zainal Asikin. 2004. Pengantar Metode Penelitian Hukum. Jakarta: Raja Grafindo Persada.

2) Asshiddiqie Jimly, Konstitusi \& Konstitusionalisme Indonesia, Ed. I, Cet. 2, Jakarta: Sinar Grafika, 2011.

3) Asshiddiqie Jimly, Hukum Tata Negara dan Pilar-Pilar Demokrasi, Ed.2, Cet.2, Jakarta: Sinar Grafika, 2012.

4) Bisri A. Zaini dan Amirudin, Pilkada Langsung: Problem dan Prospek, Pustaka Pelajar, Yogyakarta, 2006.

5) Budiarjo Mirriam, Dasar-dasar Ilmu Politik, Gramedia Pustaka, Jakarta, 2009.

6) Rahardjo Satjipto, Membedah Hukum Progresif, Penerbit Buku Kompas, 2008.

7) Rahardjo Satjipto, Hukum Progresif Sebuah Sintesa Hukum Indonesia, Genta Publishing, Yogyakarta, 2009.

8) Rasyid Ryass dan Saukani HR, Affan Gaffar, Otonomi Daerah dalam Negara Kesatuan, Pustaka Pelajar, Yogyakarta, 2002.

9) Rivai Ahmad, Penemuan Hukum Oleh Hakim Dalam Perspektif Hukum Progresif, Sinar Grafika, Jakarta, 2010.

10) Thaib Dahlan, Implementasi Sistem Ketatanegaraan Menurut UUD 1945, Liberty, Yogyakarta, 1993.

\section{Law And Regulations}

1) Pasal 103 Undang-Undang Nomor 32 Tahun 2004 Jo Pasal 6 ayat (2) huruf b angka 1 dan 3 Peraturan Mahkamah Konstitusi Nomor 15 Tahun 2008.

2) Undang-Undang Nomor 10 Tahun 2016 tentang pemilihan Gubernur, Bupati, dan Walikota, Pasal 7 ayat (2) huruf g.

3) Undang-Undang Republik Indonesia Nomor 15 Tahun 2011 Pasal 1 ayat 1 Tentang Penyelenggaraan Pemilihan Umum.

\section{Court Decisions}

1) Indonesia, Undang-Undang Nomor 10 Tahun 2016 tentang Pemilian Kepala Daerah, Lembaran Negara Nomor 130.

2) Mahkamah Konstitusi, Putusan Nomor 4/PUU-VI/2009, h. 80.

3) Mahkamah Konstitusi, Putusan Nomor 42/PUU-XIII/2015, h. 74.

4) Mahkamah Konstitusi, Putusan Nomor 42/PUU-XIII/2015, h. 68.

5) Mahkamah Konstitusi, Putusan Nomor 56/PUU-XVII/2019, h. 59.

6) Perbaikan permohonan Perkara Nomor 56/PUU-XVII/2019 oleh ICW dan Perludem, tertanggal 18 Oktober 2019 , h.26. 